\title{
Prekmursko besedje za gospodarska poslopja, kmečko dvorišče in kmečka opravila v Pleteršnikovem slovarju
}

\author{
Mihaela Koletnik \\ Univerza v Mariboru, Filozofska fakulteta, Koroška cesta 160, \\ SI-2000 Maribor, mihaela.koletnik@um.si
}

SCN VIII/1 [2015], 165-187

\begin{abstract}
V prispevku je v obsegu, določenim z vprašalnico za Slovenski lingvistični atlas (SLA), predstavljeno besedje, ki v prekmurskem narečju poimenuje gospodarska poslopja, kmečko dvorišče in kmečka opravila. V treh krajevnih govorih (cankovskem, večeslavskem in graškem), zajetih v mrežo krajev za SLA, smo zbrali sedeminštirideset različnih odgovorov na šestinpetdeset vprašanj. Dokumentiranost in semantiko obravnavane leksike smo preverili v Murkovem slovarju (1833), Pleteršnikovem slovarju (1894/95), Slovarju slovenskega knjižnega jezika in treh slovarjih, ki prinašajo prekmursko narečno besedje.
\end{abstract}

This article presents lexemes denoting farm buildings, farmyards, and farm chores in the Prekmurje dialect to the extent specified in the questionnaire used for the Slovenian Linguistic Atlas (SLA). Forty-seven replies to 56 questions were collected in three local dialects included in the SLA network of towns: Cankova (SLA 387), Večeslavci (SLA 397), and Grad (SLA 398). Documentation and semantics of the dialectal vocabulary were checked in Murko's dictionary (1833), Pleteršnik's dictionary (1894/95), in the Dictionary of Standard Slovene as well as in three more dictionaries that include the Prekmurje dialect vocabulary.

Ključne besede: kmečka materialna in kulturna dediščina, panonska narečna skupina, prekmursko narečje, Slovenski lingvistični atlas

Key words: material and cultural heritage of peasantry, Pannonian dialect group, Prekmurje dialect, Slovene Linguistic Atlas

\section{Uvod}

V prispevku je predstavljeno besedje za gospodarska poslopja, kmečko dvorišče in kmečka opravila $\mathrm{v}$ treh prekmurskih krajevnih govorih, zajetih $\mathrm{v}$ mrežo krajev za SLA: cankovskem, večeslavskem in graškem. Ti govori se uvrščajo 
v prekmursko narečje panonske narečne skupine, prvi v prekmursko ravensko, preostala dva govora pa v prekmursko goričko podnarečje. ${ }^{1}$ Obravnavano besedje je v vprašalnici za Slovenski lingvistični atlas (SLA) uvrščeno v poglavja III. Hiša (27 vprašanj), IV. Vas (4 vprašanja), VI. Orodje (14 vprašanj), VII. Živali (2 vprašanji), VIII. Rastline (7 vprašanj) in XII. Pokrajina (1 vprašanje), eno vprašanje pa najdemo tudi v gramatičnem delu vprašalnice. V Dialektološki sekciji Inštituta za slovenski jezik Frana Ramovša ZRC SAZU v Ljubljani so vprašanja prerazvrstili v smiselni sklop »gospodarska poslopja in kmečko dvorišče« (38 vprašanj), ki smo mu dodali še sklop »kmečka opravila« (18 vprašanj).

Narečno gradivo za šestinpetdeset vprašanj, obravnavanih v tem prispevku, je zbrano na Cankovi (SLA 387), v Večeslavcih (SLA 397) in pri Gradu (SLA 398). ${ }^{2}$ Dokumentiranost in semantiko zbrane leksike smo preverili v dveh starejših slovenskih slovarjih (Murko, 1833; Pleteršnik, 1894/95), v Slovarju slovenskega knjižnega jezika (1995) ter treh slovarjih, ki prinašajo prekmursko narečno besedje (Slovar beltinskega prekmurskega govora, 1996; Porabsko-knjižnoslovensko-madžarski slovar, 2005; Slovar Gornjega Senika A-L, 2009).

\section{Gradivo $z$ razširjenostjo, s pomenom in $z$ izvorom leksemov}

\section{(1) SLA V164 'stranišče'}

T387: 'xa:jzl, s'ra:unjjek; T397: 'xa:jzl, s'ra:unjjek; T398: s'ra:unjek

Za pomen 'prostor za opravljanje potrebe', knj. straníšče (i), se uporablja leksem sralnjek, izpeljanka iz leksema srati, pslovan. *sbräti, sed. *ser'Q̄' 'srati' (SES: 690); na Cankovi in v Večeslavcih sobiva z leksemom hajzelj, prevzetim iz bav. avstr. Häuslein, nar. haisel (DLS: 141; ESSJ I: 230), ki ga za obravnavani pomen poznajo tudi $\mathrm{v}$ slovenskogoriškem in prleškem narečju. V slovenskogoriškem narečju ima novejšo dvojnico vece, prevzeto iz angl. w. c. v enakem pomenu, kar je kratica, ki stoji za water closet 'sobica za vodo' (SES: 809), v prleškem narečju pa se uporablja še iz nemščine prevzeti leksem sekret $<$ nem. Sekret 'stranišče', kar se je razvilo iz srvnem. secrēt(e) < it. (luogo) segréto 'oddaljena soba' (SES: 645).

Dokumentiranost v slovarjih:

Murko: hajzelj: -; sralnjek: - Pleteršnik: hajzelj: -; sralnjek: - SSKJ: hajzelj-; sralnjek: - SBG: hajzelj: -; sràunjek -a m stranišče $\sim$ PKMS: hajzelj: -; sralnjek: $-\sim$ SGS: $\varnothing$

\footnotetext{
${ }^{1}$ Več o prekmurskem narečju in njegovih podnarečjih gl. Koletnik (2008), Koletnik, Holsedl (2009: 173-187), Zorko (2009).

${ }^{2}$ Gradivo (vprašanja 1-38) je pod mentorstvom Mihaele Koletnik leta 2013 zbrala Mateja Sever; gradivo za vprašanja 39-56 je leta 2014 zbrala Mihaela Koletnik.
} 


\section{(2) SLA V573 'gnoj'}

T387: g'nọ:j; T397: g'nọ:j; T398: g'nọ:j

Za pomen 'iztrebki domačih živali, pomešani s steljo’, knj. gnój (ộ), se uporablja enotno poimenovanje gnoj, pslovan. * gnöj (SES: 178), za obravnavani pomen posplošeno tudi v slovenskogoriškem in prleškem narečju.

Dokumentiranost v slovarjih:

Murko: Gnój, 2. gnója, gnojá m der Dung, der Mist Pleteršnik: gnộj, m. 1) der Mist, der Dünger $\sim$ SSKJ: gnój -á in - $a$ m 1. iztrebki domačih živali, pomešani s steljo $\sim$ SBG: gnój -á s gnoj PKMS: gnój -á m gnoj SGS: g'nợj-a m 1. gnojilo

\section{(3) SLA V161(s) 'hlev'}

T387: š'tåla; T397: š'tåla; T398: š'tåla

Za pomen 'stavba, prostor za bivanje domačih živali, zlasti večjih', knj. hlév (ẹ), se povsod uporablja poimenovanje štala. Leksem štala, prevzet ali iz srvnem. stal, -lles 'prostor za živino, hlev' (DLS: 227) ali iz it. stalla 'ograjen in pokrit prostor za živino’ (ESSJ IV: 105), je za obravnavani pomen posplošen tudi v slovenskogoriškem in prleškem narečju.

Dokumentiranost v slovarjih:

Murko: Shtála, f. der Stall $\sim$ Pleteršnik: štála, f. = hlev, der Stall; - iz nem. $\sim$ SSKJ:

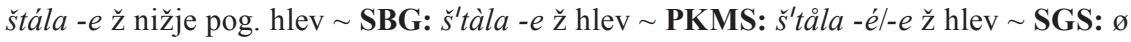

\section{(4) SLA V161(a) '(hlev) za krave'}

\section{T387: š'tåla; T397: š'tåla; T398: š'tåla}

Vprašanje za hlev (V161) predvideva še tri odgovore, in sicer za (a) hlev za krave, (b) hlev za ovce in (c) hlev za svinje. Za pomen 'stavba, prostor za bivanje goveda', knj. govéji hlév $(\bar{e}, \bar{e})$, se povsod uporablja prevzeti leksem štala, za obravnavani pomen posplošen tudi v slovenskogoriškem in prleškem narečju. V prleškem narečju sobiva z leksemom kravja štala, katerega določilo je domače (prim. pslovan. *körva /SES: 319/).

Dokumentiranost v slovarjih:

Murko: Shtála, f. der Stall Pleteršnik: štála, f. = hlev, der Stall; - iz nem.; hlẹv, m. der Viehstall /.../ - der Schweinstall SSKJ: štála -e ž nižje pog. hlev SBG: štàla -e ž hlev $\sim$ PKMS: štåla -él-e ž hlev $\sim$ SGS: $\varnothing$

\section{(5) SLA V161(b) '(hlev) za ovce'}

T387: š'tåla; T397: šttåla; T398: š'tåla 
Za pomen 'stavba, prostor za bivanje ovac', knj. ôvčji hlév (ōe ẹ), se povsod uporablja prevzeti leksem štala, za obravnavani pomen posplošen tudi v slovenskogoriškem in prleškem narečju. V prleškem narečju se rabi še leksem ovčja štala, katerega jedro je domače (prim. pslovan. *ovbcä /SES: 483/).

Dokumentiranost v slovarjih:

Murko: Shtála, f. der Stall Pleteršnik: štála, f. = hlev, der Stall; - iz nem.; hlẹ́v, m. der Viehstall /.../ - der Schweinstall SSKJ: štála $-e$ ž nižje pog. hlev SBG: š́tàla -e ž hlev PKMS: šttåla -él-e ž hlev SGS: ø

\section{(6) SLA V161(c) '(hlev) za svinje'}

T387: š'tålce; T397: s'vinjska š'tåla, s'vinjske š'tålce; T398: lo'viiạčig, s'vinjske š'tålce

Za pomen 'stavba, prostor za bivanje svinj', knj. svínjski hlév $(i, e \bar{e})$, se uporabljata besedna zveza svinjska štala, katere jedro je prevzeto, določilo pa je izpeljano iz leksema svinja, pslovan. *svinï, rod. *svinbjë (SES: 715), največkrat izpričana v množinski obliki, ter v množinski obliki zabeležen leksem štalica, izpeljanka iz prevzetega leksema štala. Kot enkratnica je v T398 zapisan v množinski obliki izpričani leksem lovič, izpeljanka iz glagola loviti, pslovan. *loviti s prvotnim pomenom 'ujeti, zapleniti' (SES: 366), ki ima izpričano dvojnico svinjske štalice. Leksem svinjska štala je posplošen tudi na sklenjenem območju slovenskogoriškega in prleškega narečja; v prvem sobiva z leksemom štalica, izpričanim v množinski obliki, v drugem pa z leksemi: štalinka in štalinec, izpeljankama iz leksema štala, ter svinjak, izpeljanko iz leksema svinja, pslovan. *svinï, rod. *svinbjë (SES: 715).

Dokumentiranost v slovarjih:

Murko: lovič: -, toda lòvzh, m. der Häscher; svinjska štala: -; svinjske štalice: -; Shtáliza, f. d. ein kleiner Stall Pleteršnik: lóvič, m. der Häscher, Mur.; svinjska štala: -; svinjske štalice: -; štalica - SSKJ: lovič: -; svinjska štala: -; svinjske štalice: -; štálica -e ž nižje pog. hlevček SBG: lovič: -; svinjska štala: -; svinjske štalice: -; štalica - PKMS: lovič: -; svinjska štala: -; svinjske štalice: -; štalica - SGS: lovič: -; svinjska štala: ø; svinjske štalice: ø; štalica: ø

\section{(7) SLA V161(a) 'kurnica (kjer spijo kokoši)'}

T387: koko'šečnjek; T397: 'kürnjek; T398: 'kürnjek

Za pomen 'zaprt prostor za kokoši', knj. kúrnik (̂̂), se najpogosteje uporablja leksem kurnjak, izpeljanka iz leksema kura, pslovan. *küra 'kokoš' (SES: 335). Kot enkratnica je v T387 izpričan leksem kokošečnjak, izpeljanka iz leksema kokoš, pslovan. *kökošb, kar je izpeljano iz onomatopeje *koko, ki posnemma kokodakanje (SES: 290; ESSJ II: 54). Leksem kurnjak je za obravnavani pomen posplošen tudi v slovenskogoriškem in prleškem narečju; $\mathrm{v}$ slednjem sobiva z 
leksemom kurečjak, v prvem pa poznajo še lekseme kurečjak, kurečnik, kurešnica, kurjek, kurnica in kurnik.

Dokumentiranost v slovarjih:

Murko: kokošečnjak: -; kúrnjak m. die Hühnersteige Pleteršnik: kokošečnjak: -, toda kokošnják, m. 1) = kurnjak, Cig.; kûrnjak, m. = kurnik 1), Mur., Cig., Jan., Valj. (Rad), Bes. SSKJ: kokošečnjak: -, toda kokošnjak; kúrnjak - a m star. kurnik, kokošnjak SBG: kokošečnjak: -; kurnjak: - PKMS: kokošečnjak: -; kürnjek-a m kurnik $\sim$ SGS: kokošečnjak: -; 'kü:rn'ek-a m kurnik

\section{(8) SLA V162A 'skedenj'}

T387: š'kegenj; T397: š'kegenj; T398: š'kegenj

Za pomen 'gospodarsko poslopje z delovnim prostorom zlasti za mlatenje in s prostorom za shranjevanje sena, slame', knj. skedènj in skèdenj (ä; ̀̀), je v gradivu izpričano poimenovanje skedenj, prevzeto iz stvnem. scugin, scugina 'skedenj, gumno' (ESSJ III: 242), kar poznajo tako v slovenskogoriškem kot prleškem narečju.

Dokumentiranost v slovarjih:

Murko: Skèdenj, auch fkédenj, dnja m. die Tenne, der Dreschboden $\sim$ Pleteršnik: skadànj, -dnjà, m. die Scheune, die Scheuer; der Dreschboden, die Tenne, Mur., Cig. tudi: skàdənj, Štrek. - prim. skegenj, škegen, stvn. scugin, scugina, Scheune, Mik. (Et.) $\sim$ SSKJ: skedènj -dnjà in skèdenj -dnja m gospodarsko poslopje z delovnim prostorom zlasti za mlatenje in s prostorom za shranjevanje sena, slame $\sim$ SBG: škègen(j) -gnja m sadovnjak; drugod v Prekmurju skedenj $\sim$ PKMS: škèdjen -dnja m skedenj $\sim$ SGS: $\varnothing$

\section{(9) SLA V162A(p) Če je beseda znana, določiti pomen.}

Vprašanje za skedenj (V162A) zahteva tudi razlago pomena. V prekmurskem goričkem in ravenskem podnarečju se leksem skedenj uporablja za pomen 'prostor za shranjevanje sena, slame'.

\section{(10) SLA V162B 'petra'}

Beseda v prekmurščini ni znana, prav tako ne v slovenskogoriškem in prleškem narečju.

(11) SLA V162B(p) Če je beseda znana, določiti pomen.

Gl. (10) V162B.

\section{(12) SLA V162C 'gumno'}

T387: 'gümla; T397: 'gümla; T398: 'gümla 
Za pomen 'prostor, kjer se navadno mlati', knj. gúmno (ú), se uporablja enotno, $\mathrm{v}$ feminizirani obliki izprčano poimenovanje gumno, pslovan. *gumbnö *'prostor, kjer se mlati pšenica' (SES: 96), za obravnavani pomen posplošeno tudi v slovenskogoriškem in prleškem narečju

Dokumentiranost v slovarjih:

Murko: Gúmno n. die Dreschtenne Pleteršnik: gúmno, n. 1) festgestampfter Boden: die Tenne, die Dreschtenne, Mur., Cig., Jan., ogr.-Mik. SSKJ: gúmno - a s prostor, kjer se navadno mlati $\sim$ SBG: gümlo $-a$ s gumno; kolnica; pod za mlačev $\sim$ PKMS: gümla -e ž gumno $\sim$ SGS: 'gümlo - $a$ s gumno

\section{(13) SLA V168A 'studenec'}

T387: s'tüdenec; T397: s'tüdenec; T398: s'tüdenec

Za pomen 'manjši izvir vode', knj. studênec (é), se uporablja enotno poimenovanje studenec. Leksem studenec, slovan. *studenbcü, kar je izpeljano iz pslovan. *studenž 'mrzel' (SES: 708), je za obravnavani pomen posplošen tudi v slovenskogoriškem (tukaj z različico studenek) in prleškem narečju.

Dokumentiranost v slovarjih:

Murko: studenec: -, toda ‘Stúdeniz, nza m der Brunnen Pleteršnik: studénac m. 1) die Quelle /.../ - tudi: stûdenəc, Valj. (Rad), vzh ̌̌t. SSKJ: studênec-nca m 1. manjši izvir vode $\sim$ SBG: stǜdenec $-n c a$ m vodnjak, studenec $\sim$ PKMS: stüdenec $-n c a \mathrm{~m}$ vodnjak, studenec $\sim$ SGS: $\varnothing$

\section{(14) SLA V168B 'vodnjak'}

T387: s'tüdenec; T397: s'tüdenec; T398: s'tüdenec

Za pomen 'zaprt prostor ali posoda, navadno v zemlji, za zbiranje, shranjevanje večjih količin pitne vode', knj. vodnják (á), se uporablja enotno poimenovanje studenec, za obravnavani pomen posplošeno tudi v slovenskogoriškem (tukaj $\mathrm{z}$ različico studenek) in prleškem narečju, kjer sobiva z leksemom studenec $z$ vedrico.

Dokumentiranost v slovarjih:

Murko: studenec: -, toda Stúdeniz, nza m der Brunnen $\sim$ Pleteršnik: studénac m. 1) die Quelle /.../ - tudi: stûdenəc, Valj. (Rad), vzhŠt. SSKJ: studênec -nca m 1. manjši izvir vode $\sim$ SBG: stǜdenec $-n c a$ m vodnjak, studenec $\sim$ PKMS: stüdenec $-n c a \mathrm{~m}$ vodnjak, studenec $\sim$ SGS: $\varnothing$

\section{(15) SLA V169(s) 'korito'}

T387: ko'rito; T397: ko'rito; T398: ko'rito 
Splošno vprašanje 'korito' (V169) predvideva natančnejše odgovore za (a) korito za vodo in (b) korito za prašiče. Dalje gl. (16) V169(a) in (17) V169(b).

\section{(16) SLA V169(a) 'korito za vodo'}

T387: ko'rito; T397: ko'rito; T398: ko'rito

Za pomen 'večja podolgovata, navadno zidana posoda na prostem za vodo', knj. korito (i), se uporablja enotno poimenovanje korito, pslovan. *korÿto 'korito, žleb' (SES: 310), za obravnavani pomen posplošeno tudi v slovenskogoriškem in prleškem narečju.

Dokumentiranost v slovarjih:

Murko: Korito n. der Trog, eine grosse Rinne $\sim$ Pleteršnik: korito, n. der Trog (Fress-, Tränke-, Löschtrog u. dgl.) SSKJ: korito - $a$ s 1. podolgovata, navadno lesena posoda za krmljenje, napajanje živine $\sim$ SBG: korito $-a$ s korito $\sim$ PKMS: korito $-a$ s korito $\sim$ SGS: $k o^{\prime}$ ritta $-e$ ž korito

\section{(17) SLA V169(b) 'korito za prašiče'}

T387: ko'pånja; T397: ko'pånja; T398: ko'pånja

Za pomen 'podolgovata, navadno lesena posoda za krmljenje, napajanje živine, knj. korito (i), se uporablja leksem kopanja, izpeljanka iz splošnoslovanskega leksema kopati 'delati jamo', pslovan. *kopäti 'kopati', kar izhaja iz ide. kore-

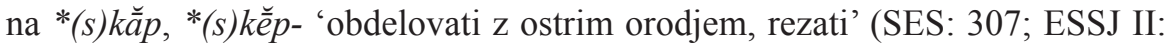
44). Leksem kopanja poznajo tudi v slovenskogoriškem in prleškem narečju; v prvem sobiva z leksemi korito, svinjsko korito in korito za napajati, v drugem z leksemom svinjsko korito.

Dokumentiranost v slovarjih:

Murko: Kopánja f. der Trog Pleteršnik: kopánja, f. der Badetrog, der Trog, Mur., Št., Cig., Jan., ogr.-C. SSKJ: kopánja -e ž 1. nar. vzhodno podolgovata, navadno lesena posoda za krmljenje, napajanje živine; korito $\sim$ SBG: kopànja $-e$ ž korito $\sim$ PKMS: kopånja -e ž korito, kad $\sim$ SGS: ko'pån'a -e ž 1. korito

\section{(18) SLA V170 'tnalo (kos lesa, na katerem sekajo drva)'}

T387: 'pẹ:n; T397: 'pẹ:n; T398: 'pẹ:n

Za pomen 'nerazsekan, večji kos debla, na katerem sekajo, cepijo drva', knj. tnálo (á), se uporablja leksem panj, pslovan. * pön'b 'štor, parobek' (SES: 490). $\mathrm{V}$ slovenskogoriškem in prleškem narečju leksema panj ne poznajo. V obeh omenjenih narečjih je najpogostejše poimenovanje štor $\left(<\right.$ bav. srvnem. ${ }^{*}$ stor /DLS: 230; ESSJ IV: 116/); v slovenskogoriškem narečju se rabita še leksema štor za drva cepati in ritka, metaforična izpeljanka iz leksema rit, pslovan. 
*rïtb (ESSJ: 183, 184), v prleščini pa poznajo leksem naton, izpeljan iz tęti, tbno (ESSJ II: 216).

Dokumentiranost v slovarjih:

Murko: Pánj, m. der Stock, dr Block, der Bienenstock, der Baumstamm Pleteršnik: pânj, pânja, panjâ, panjû, m. 1) das stecken gebliebene Stück eines abgehauenen Baumes, der Baumstock $\sim$ SSKJ: pánj $-a \mathrm{~m} 2 . / \ldots /$ po podiranju drevja preostali del debla; štor $\sim$ SBG: pén - $a$ m štor; tnalo; panj PKMS: pén - $a$ m panj $\sim$ SGS: $\varnothing$

\section{(19) SLA V170(p) Ali ima beseda tnalo drug pomen?}

Vprašanje $170(\mathrm{p})$ sprašuje po morebitnih pomenskih premikih. Ti v gradivu niso zabeleženi.

\section{(20) SLA V158A 'drva'}

T387: 'drva; T397: 'drva; T398: 'drva

Za pomen 'razžagan in navadno naklan les za kurjavo', knj. dŕva (ŕ), se uporablja enotno poimenovanje $d r v a$, pslovan. *drъvä (SES: 127), za obravnavani pomen posplošeno tudi $\mathrm{v}$ slovenskogoriškem in prleškem narečju.

Dokumentiranost v slovarjih:

Murko: drva: -, toda Drova, n. pl. (coll) das Brennholz Pleteršnik: dŕva, n. pl. išči pod: drvo; dŕvo, n. /.../ nav. pl. dŕva, das Brennholz SSKJ: dŕva dŕv in drvà dŕv $\mathrm{s}$ mn. razžagan in navadno naklan les za kurjavo $\sim$ SBG: drva: - PKMS: dŕva (pl.) drva SGS: 'dra 'drf mn. drva

\section{(21) SLA V317 'poleno'}

\section{T387: pre'kåư⿱ T397: pre'kåư⿱ T398: pre'kåu}

Za pomen 'razžagan, neobdelan kos lesa za kurjavo', knj. poléno (é), se uporablja leksem prekal, izpeljanka iz leksema prekalati 'razpoloviti' (Novak 1996: 112), tvorjenega iz leksema kalati, pslovan. *kaläti (SES: 250). V slovenskogoriškem in prleškem narečju leksema prekal ne poznajo. V obeh narečjih se uporabljata poimenovanji poleno, pslovan. polëno '*kar gori' (ESSJ III: 80), in drvo, izpričano v ženskospolski obliki, v slovenskogoriškem narečju pa še leksemi cepanica (prim. pslovan. *cếpati, kar je izpeljano iz *cépъ 'razcepljen kos lesa'/SES: 70/), kalanica (prim. pslovan. *kaläti 'cepiti drva'/SES: 250/), ploh, kar je ali prevzeto iz srvnem. bloch, bloc, bav. nem. ploch 'ploh' ali izpeljano iz nar. slovenskega pridevnika plöh 'plosk' (SES: 528; ESSJ III: 60; DLS: 197), špelta (< srvnem. spëlte 'odklan kos lesa, razkolek' /ESSJ: 89; DLS: 223/) in šplevta (< bav. nem. Splette, Splête 'lesen razkolek' /ESSJ: 101/). Dokumentiranost v slovarjih: 
Murko: prekal: - Pleteršnik: prekal- SSKJ: prekal - SBG: prekal-; gl. prekálati -an razpoloviti $\sim$ PKMS: prekal: $-\sim$ SGS: $\varnothing$

\section{(22) SLA V158B 'butara (nasekano dračje ali vejevje, povezano v snop)'}

T387: 'püšeun (veja); T397: 'püšeu (veja); T398: 'püšeun (veja)

Za pomen 'več kratko nasekanih in povezanih vej za kurjavo', knj. bútara (ú), se uporablja leksem pušelj, prevzet iz bav. avstr. nem. Puschel 'šopek', kar je manjšalnica k Pusch 'grm' (DLS: 205; ESSJ: 138). Leksem pušelj za obravnavani pomen poznajo tudi v slovenskogoriškem in prleškem narečju; v prvem sobiva z leksemi bašelj (< rom. fascis 'sveženj, snop' /ESSJ I: 13/), snopič (prim. pslovan. *snopž /SES: 677/), butara (< madž. bútor 'cula, prtljaga, pohištvo' ali morda slovansko /SES: 6; ESSJ I: 55/) in breme (< pslovan. *bérmę 'breme' /SES: 56/), v drugem pa z leksemi butara, pušlek in šibje (< šiba, pslovan. *šl'ba /SES: 725/).

Dokumentiranost v slovarjih:

Murko: Púfhelj (†) 2. púfhlja, púfhljna m. der Bund, der Strauss, der Blumenstrauss, der Buschen Pleteršnik: pušelj: - SSKJ: púšelj -šlja m nar. šop SBG: püšeu -šla m šop, butara PKMS: pǚšeu -šla m šopek, pušel (nar.) SGS: ø

\section{(23) SLA V171 'cepiti (drva na drobno)'}

T387: 'ka:lati;; T397: 'ka:lati; T398: 'ka:lati

Za pomen 'po dolgem razsekovati, kalati', knj. cepiti in cépiti $(\bar{l}, e$ é), se uporablja leksem kalati, pslovan. *kaläti (SES: 250), kar poznajo tudi v slovenskogoriškem in prleškem narečju; prvo za obravnavani pomen beleži še leksem cepati (pslovan. *ce̋́pati /SES: 70/), drugo pa sekati (pslovan. *sě̌kati (ali *sěkäti) /SES: 645/).

Dokumentiranost v slovarjih:

Murko: Kálati, am v. impf. spalten $\sim$ Pleteršnik: kâlati, -am, vb. impf. spalten, schlitzen, Mur., Cig., Jan. $\sim$ SSKJ: kálati - am nedov. redko cepiti, klati $\sim$ SBG: kálati $-a n$ cepiti (drva), klati $\sim$ PKMS: kálati -an cepiti (drva) SGS: 'ka:late -an nedov. cepiti

\section{(24) SLA V171(p) Določiti pomen.}

Vprašanje 171 zahteva tudi določitev pomena. Iz pojasnil k rabi leksema kalati izhaja, da se ta rabi za pomen 'po dolgem razsekovati, klati drva'.

\section{(25) SLA V171(a) 'sekati'}

T387: 'sẹkatị; T397: 'sẹkati̊; T398: 'sẹkatị 
Za pomen ' $\mathrm{z}$ udarjanjem $\mathrm{z}$ ostrim predmetom delati kose, dele', knj. sékati (é), se povsod uporablja leksem sekati, pslovan. *sěkkati (ali *sěkäti) (SES: 645), kar ob leksemu kalati poznajo tudi v slovenskogoriškem in prleškem narečju; prvo za obravnavani pomen beleži še leksem cepati.

Dokumentiranost v slovarjih:

Murko: sẹ́kati, sệkam, vb. impf. hacken, hauen Pleteršnik: sẹ́kati, sệkam, vb. impf. hacken /.../ drva s., Holz hacken $\sim$ SSKJ: sékati -am nedov. 1. z udarjanjem z ostrim predmetom a) delati kose, dele: ves dan so sekali drva SBG: sèkati -éikan sekati PKMS: sèjkati/sékati sèjkan sekati SGS: $\varnothing$

\section{(26) SLA V171(a)(p) Določiti pomen.}

Vprašanje 171 (a)(p) zahteva tudi določitev pomena. Iz pojasnil k rabi leksemov kalati in sekati izhaja, da se leksem kalati uporablja v pomenu 'sekati drva', leksem sekati pa v pomenu 'sekati suhljad, dračje'.

\section{(27) SLA V315(s) 'sekira'}

T387: se'kẹ:ra; T397: se'kẹ:ra; T398: se'kẹ:ra

Za pomen 'orodje za sekanje iz držaja in na njem nasajenega rezila', knj. sekíra (i), se uporablja enotno poimenovanje sekira, pslovan. *sekÿra (sekundarno sěkÿra) (SES: 645), kar je za obravnavani pomen posplošeno tudi v slovenskogoriškem in prleškem narečju.

Dokumentiranost v slovarjih:

Murko: Sekíra, sekjíra f. die Hacke, das Beil Pleteršnik: sẹkira, f. die Axt SSKJ: sekira $-e$ ž orodje za sekanje iz držaja in na njem nasajenega rezila $\sim$ SBG: sekira: -

PKMS: sekéra $-e$ ž sekira $\sim$ SGS: $\varnothing$

\section{(28) SLA V315(a) 'navadna (sekira)'}

Vprašanje za sekiro (V315) predvideva odgovore za (a) navadno sekiro in (b) tesarsko sekiro. Za pomen 'navadna sekira' se v prekmurščini uporablja leksem sekira. Ta je za obravnavani pomen posplošen tudi v slovenskogoriškem in prleškem narečju. V prvem sobiva z leksemi drvanica, tepača in cepanica, v drugem z leksemi flosarka (prim. nem. Flösserhacke), drvača in drvnica, izpeljankama iz leksema drva.

\section{(29) SLA V315(b) 'tesarska (sekira)'}

T387: 'ci:mermanska se'kẹ:ra; T397: 'cirmermanska se'kẹ:ra; T398: 'ci:mermanska se'kẹ:ra

Za pomen 'tesarska sekira' se uporablja večbesedni leksem cimermanska sekira, katerega določilo je izpeljano iz prevzete podstave (prim. nem. Zimmerman 'te- 
sar'), jedro pa je domače, ki ga poznajo tudi v slovenskogoriškem in prleškem narečju. V prvem sobiva z leksemi cimerača $(<$ nem. Zimmerhacke), tesača in bognarica (< madž. bognár 'kolar'), v drugem pa z leksemi cimermanka, cimerača (< nem. Zimmerhacke), sekira, plankača $(<$ srvnem. planke, lat. planca 'deska, ograja'/SES: 521/) in tesarica.

Dokumentiranost v slovarjih:

Murko: cimermanska sekira: $-\sim$ Pleteršnik: cimermanska sekira: $-\sim$ SSKJ: cimermanska sekira: $-\sim$ SBG: cimermanska sekira: $-\sim$ PKMS: cimermanska sekira: $-\sim$ SGS: cimermanska sekira: -

\section{(30) SLA V316 'toporišče (pri sekiri)'}

T387: š'tiư⿱ T397: š'tiư; T398: š'tiu

Za pomen 'daljši držaj pri orodju', knj. toporíšče (i), se uporablja enotno poimenovanje štil. Leksem štil, prevzet iz srvnem stil, iz česar se je razvilo današnje nemško Stiel 'držaj, ročaj' (SES: 740), je za obravnavani pomen posplošen tudi v slovenskogoriškem in prleškem narečju.

Dokumentiranost v slovarjih:

Murko: štil: $-\sim$ Pleteršnik: štil: $-\sim$ SSKJ: štil: $-\sim$ SBG: štíu -ila m ročaj $\sim$ PKMS: štil: $-\sim$ SGS: $\varnothing$

\section{(31) SLA V438 'tesati'}

T387: te'såtị; T397: te'såtị; T398: te'såti

Za pomen 's sekiro obdelovati les v smeri vlaken', knj. tesáti (á), se uporablja enotno poimenovanje tesati, pslovan. *tesäti (SES: 761), za obravnavani pomen posplošeno tudi v slovenskogoriškem in prleškem narečju. V prvem se uporablja še leksem sekati ven, v drugem pa leksem sekati.

Dokumentiranost v slovarjih:

Murko: Tèfati oder téfati, gem. tefáti, téfhem oder tèfhem v. imp. behauen, wie die Zimmerleute $\sim$ Pleteršnik: tésati, tẹ́šem, vb. impf. 1) behauen, zimmern $\sim$ SSKJ: tesáti téšem nedov. s sekiro obdelovati les v smeri vlaken $\sim$ SBG: tesàti tèšen tesati $\sim$ PKMS: tèsati tèšen tesati SGS: $\varnothing$

\section{(32) SLA V437 'žagati’}

T387: 'žågatị; T397: 'žågatị; T398: 'žågatị

Za pomen 's potegovanjem žage sem in tja ali z njenim premikajočim se listom delati kose, dele', knj. žágati (â), se uporablja enotno poimenovanje žagati. 
Leksem žagati, izpeljan iz leksema žaga, prevzetega iz stvnem. saga 'žaga' (DLS: 248), je za obravnavani pomen posplošen tudi v slovenskogoriškem in prleškem narečju.

Dokumentiranost v slovarjih:

Murko: Shágati, am v. impf. sägen $\sim$ Pleteršnik: žâgati, -am, vb. impf. sägen $\sim$ SSKJ: žágati -am nedov. 1. s potegovanjem žage sem in tja ali z njenim premikajočim se listom a) delati kose, dele $\sim$ SBG: žagati: $-\sim$ PKMS: žågati žágan žagati $\sim$ SGS: $\varnothing$

\section{(33) SLA V156 'hlod'}

T387: p'lọ:(j); T397: p'lọ:(j); T398: p'lọ:(j)

Za pomen 'odžagano, debelejše deblo brez vej', knj. hlód (ọ), se uporablja enotno poimenovanje ploh. Leksem, ali prevzet iz srvnem. bloch, bloc, bav. nem. ploch 'ploh' ali izpeljan iz nar. sloven. pridevnika plöh 'plosk' (SES: 528; ESSJ III: 60; DLS: 197), za obravnavani pomen poznajo tudi v slovenskogoriškem in prleškem narečju; v slednjem se uporabljajo še lekseme ril, pslovan. *rÿlı (ESSJ: 180), hlod, pslovan. *hlodb̀ (SES: 206), in hojka, pslovan. *xvojä 'smrečje' (SES: 208).

Dokumentiranost v slovarjih:

Murko: Plòh, m. der Hackstock Pleteršnik: plòh, plóha, m. 2) der Baumstamm, aus dem Bretter gesägt werden, C., Poh. - prim. kor.-nem. ploch, Block SSKJ: plòh plôha $\mathrm{m}$ debelejši ploščat kos lesa iz podolžno razžaganega debla $\sim$ SBG: ploh: $-\sim$ PKMS: ploh: -; gl. plójek hlod SGS: ø

\section{(34) SLA V436(a) 'deska - splošno'}

T387: b'lånja; T397: b'lånja; T398: b'lånja

Za pomen 'ploščat kos lesa iz podolžno razžaganega debla', knj. deskà in dèska $(\ddot{a} ; \bar{\partial})$, se uporablja leksem blanja, ki je prevzet preko istr. rom. ali furl. iz dalm. rom. *plana (ESSJ I: 24). Leksem blanja v slovenskogoriškem in prleškem narečju sobiva z leksemom deska, pslovan. *dbskä, kar je prevzeto iz germ. *diska- (SES: 104).

Dokumentiranost v slovarjih:

Murko: Blánja, f. das Brett, der Laden Pleteršnik: blánja, f. 1) das Brett, Mur., Cig., Jan., SlGor.-C., ogr.-Valj. (Rad) SSKJ: blánja -e ž nar. deska SBG: blànja -e ž deska $\sim$ PKMS: blanja: - SGS: blanja: -

\section{(35) SLA V436(b) 'tanka deska'}

T387: b'lånja; T397: b'lånja; T398: b'lånja, b'lånjščica 
Za pomen 'tanka deska' se uporablja iz romanskega jezika prevzeti leksem blanja, ki ima v T398 izpričano dvojnico blanjščica. Leksem blanja poznajo tudi v slovenskogoriškem in prleškem narečju, kjer je za obravnavani pomen izpričano še poimenovanje deska. V prleškem narečju se rabita še leksema tanka deska in lata (< stvnem. latta ali srvnem. latte /SES: 346/), v slovenskogoriškem pa uporabljajo tudi leksem colarica (prim. nem. Zoll 'cola'/SES: 76/).

Dokumentiranost v slovarjih:

Murko: Blánja, f. das Brett, der Laden; blanjščica: - Pleteršnik: blánja, f. 1) das Brett, Mur., Cig., Jan., SlGor.-C., ogr. Valj. (Rad); blanjščica: - SSKJ: blánja -e ž nar. deska; blanjščica: - SBG: blànja -e ž deska; blanjščica: -, toda blánjčka -e ž deščica PKMS: blanja: -; blanjščica: - SGS: blanja: -; blanjščica: -

\section{(36) SLA V436(c) 'debela deska'}

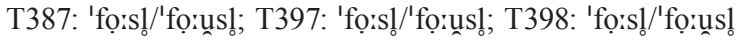

Za pomen 'debela deska' se uporablja v dveh glasoslovnih različicah izpričani leksem fosen, prevzet iz nem. Pfosten 'podboj, kol', kar je za obravnavani pomen posplošeno tudi v prleškem in slovenskogoriškem narečju; v slednjem se uporabljata še leksema debela blanja in štuk $(<$ nem. Stock 'palica' < germ. *stukka- 'palica, štor, deblo, bruno' /ESSJ IV: 124/).

Dokumentiranost v slovarjih:

Murko: fosen: $-\sim$ Pleteršnik: fosen: $-\sim$ SSKJ: fosen: $-\sim$ SBG: fosen: $-\sim$ PKMS: fosen: - SGS: 'fo:usle -na m ploh

\section{(37) SLA V785 'dleto'}

T387: g'le:intva; T397: g'le:intva; T398: g'le:intva

Za pomen 'orodje za dolbenje s kratkim prečnim rezilom', knj. dléto (é), se uporablja enotno, v feminizirani obliki izpričano poimenovanje dletvo, pslovan. *del(b) to k *dblti, *dblbo 'dolbsti' (ESSJ I: 104), kar ob leksemu dleto in štemajzen (< nem. Stemmeisen) poznajo tudi v slovenskogoriškem in prleškem narečju. V slednjem se uporabljata še različici dletvaš in dletev ter poimenovanje holbič (prim. nem. hobeln).

Dokumentiranost v slovarjih:

Murko: Dléto, auch dlé-tvo n. das Stemmeisen, der Meissel Pleteršnik: dlẹtọ, n. das Stemmeisen, der Meißel in glẹtvo, n., vzhŠt., pogl. dletvo $\sim$ SSKJ: dléto $-a$ s orodje za dolbenje s kratkim prečnim rezilom $\sim$ SBG: dleto: $-\sim$ PKMS: dleto: $-\sim$ SGS: dleto: -

\section{(38) SLA V318 'sveder'}

T387: s'vẹder; T397: s'vẹder; T398: s'vẹder 
Za pomen 'orodje z navoji za delanje lukenj, vrtin', knj. svéder (é), se uporablja enotno poimenovanje sveder, pslovan. *svërdrъ (SES: 714), za obravnavani pomen posplošeno tudi $\mathrm{v}$ slovenskogoriškem in prleškem narečju.

Dokumentiranost v slovarjih:

Murko: Svéder, dra m. der Bohrer Pleteršnik: svẹ́dər,-dra, m. 1) der Bohrer SSKJ: svéder -dra $\mathrm{m} 1$. orodje z navoji za delanje lukenj, vrtin $\sim$ SBG: sveder: $-\sim$ PKMS: sveder: - SGS: $\varnothing$

\section{(39) SLA V206 'železo'}

T387: že'lẹzo; T397: že'lẹzo; T398: že'lẹzo

Za pomen 'najbolj razširjena težka kovina srebrno bele barve', knj. želézo (é), se uporablja poimenovanje železo, pslovan. *želězzo, kar etimološko ni dokončno pojasnjeno (SES: 866). Leksem je za obravnavani pomen posplošen tudi v slovenskogoriškem in prleškem narečju.

Dokumentiranost v slovarjih:

Murko: železo: -, toda Shelésje n. (coll) eine menge Eisen, das Eisen überhaupt Pleteršnik: želézo, n. 1) das Eisen SSKJ: želézo - a s najbolj razširjena težka kovina srebrno bele barve $\sim$ SBG: železo: -, toda želéizje - a s železo PKMS: želézo - a S železo SGS: ø

\section{(40) SLA V207 'oglje'}

T387: 'vo:ungelge; T397: 'vo:ungelge; T398: 'vo:ungelge

Za pomen 'črna snov, ki nastane z žganjem lesa', knj. óglje (ọ), se uporablja leksem ogelje, izpričan tudi v slovenskogoriškem narečju. Tu sobiva z leksemi oglje in oglenje, kar poznajo tudi v prleščini, ogljije ter ogelje. Leksem ogel 'kos nedogorelega lesa', pslovan. *öglb, v enakem pomenu poznajo tudi v hrv. (ügljēn), srb. (ügalj), rus. (úgol) in češ. (úhel) jeziku (SES: 465).

Dokumentiranost v slovarjih:

Murko: ogelje: $-\sim$ Pleteršnik: ôgalje, n. coll. = oglje, Kohlen, Trub., ogr.-C. $\sim$ SSKJ: ogelje: $-\sim$ SBG: vóugelje $-a$ S oglje $\sim$ PKMS: ogelje: $-\sim$ SGS: $\varnothing$

\section{(41) SLA V386 ‘čreslo’}

$$
\text { T387: -; T397: -; T398: - }
$$

Beseda v prekmurščini ni znana. 


\section{(42) SLA V294 'mlačev'}

T387: mla'ti:intef; T397: mla'ti:itef; T398: mla'ti:itef

Za pomen 'delo, dejavnost, povezana s spravljanjem zrnja iz klasja, latja s cepcem, mlatilnico', knj. mláčev in mláčva (â), se uporablja leksem mlatitev, izpeljanka iz leksema mlatiti, pslovan. *moltïti (SES: 407). Leksem poznajo tudi v slovenskogoriškem in prleškem narečju, kjer sobiva z leksemom mlatitva. Dokumentiranost v slovarjih:

Murko: mlatitev f. das Dreschen, die Dreschzeit $\sim$ Pleteršnik: mlatîtav, -tve, f. das Dreschen, Mur., Jan., ogr.-Valj. (Rad) SSKJ: mlatítev -tve ž nar. vzhodno mlačev, mlatev $\sim$ SBG: mlatídev $-d v i$ ž mlačev $\sim$ PKMS: mlatídev/mlatitev -tve ž mlačev, mlačva $\sim$ SGS: $\varnothing$

\section{(43) SLA V188 'mleti'}

T387: m'lẹti̊;; T397: m'lẹti̊; T398: m'lẹtị

Za pomen 'z napravo drobiti žito', knj. mléti (é), se uporablja enotno poimenovanje mleti, pslovan. *mélti (SES: 407), za obravnavani pomen posplošeno tudi v slovenskogoriškem in prleškem narečju.

Dokumentiranost v slovarjih:

Murko: Mléti, mèlem oder méljem v. impf. mahlen (Getreide) Pleteršnik: mlẹti, méljem, vb. impf. 1) mahlen SSKJ: mléti méljem nedov. 1. z napravo drobiti žito SBG: mlèti se mèlen se mleti se PKMS: mléti mèlen mleti SGS: $\varnothing$

\section{(44) SLA V196 'meti'}

$$
\text { T387: -; T397: -; T398: - }
$$

Za pomen 'drobiti, treti', knj. méti (é), gradivo ne daje podatkov.

\section{(45) SLA V198 'ličkati (majiti, slačiti, kožuhati)'}

\section{T387: 'lü:ipati̊; T397: 'lü:ipati̊; T398: 'lü:inpati}

Za pomen 'odstranjevati s koruznega storža krovne liste', knj. líčkati (î), se uporablja leksem lupati z glagolsko pripono - a-ti za knj. - $i$-ti (prim. pslovan. *lupitti). Leksem lupati za obravnavani pomen poznajo tudi v slovenskogoriškem narečju, kjer sobiva z leksemoma šolati (< nem. schölen) in likati (prim. pslovan. *lîkъ 'zunanja podoba, videz, oblika'/SES: 357/); slednjega poznajo tudi v prleškem narečju, kjer se rabi še leksem kožuhati, izpeljanka iz leksema kožuh, pslovan. *koz'üx, kar je morda izpeljano iz leksema koža (ESSJ II: 77; SES: 316). 
Dokumentiranost v slovarjih:

Murko: Lúpati, pljem oder lúpiti, im v. impf. schälen (Äpfel, Rüben, Kastanien u. dgl.) $\sim$ Pleteršnik: lúpati, -pam, -pljem, vb. impf. = lupiti, schälen (von weichen Schalen und Rinden), Mur., Zora SSKJ: lúpati -ljem tudi -am nedov. nar. vzhodno odstranjevati lupino, kožo; lupiti /.../ lupati koruzo ličkati SBG: lüipati -plen lupiti, ličkati, kožuhati PKMS: lüpati -an drzati SGS: 'lü:pate -an nedov. 3. ličkati

\section{(46) SLA V198(a) 'ružiti (luščiti zrno s koruznega storža)'}

T387: 'lü:iñščitio; T397: 'lü:iňščiti; T398: 'lü:iñščiti

Za pomen 'odstranjevati zrna s storža', knj. luščiti in lúščiti $(i ; u)$, se uporablja leksem luščiti, pslovan. *luščlıti (SES: 369), kar za obravnavani pomen poznajo tudi v slovenskogoriškem in prleškem narečju.

Dokumentiranost v slovarjih:

Murko: Lúšiti, -im v. impf. schälen (Nüsse, Kukuruz u. dgl.) Pleteršnik: lúščiti, -im, vb. impf. - zrnje 1., das Getreide gerben, Cig. SSKJ: luščíti in lúščiti -im nedov 2. odstranjevati zrna s storža $\sim$ SBG: lüiiščiti -in luščiti $\sim$ PKMS: lüšččti -in luščiti $\sim$ SGS: 'lüškẹte -ẹn nedov. luščiti - 2. odstranjevati zrna s storža

\section{(47) SLA V293 'mlatiti'}

T387: m'la:titi; T397: m'la:titia; T398: m'la:titi

Za pomen 's cepcem, mlatilnico spravljati zrnje iz klasja, latja', knj. mlatīti in mlátiti $(\bar{l} ; a)$, se uporablja enotno poimenovanje mlatiti, pslovan. *moltïti (SES: 407), kar poznajo tudi v slovenskogoriškem in prleškem narečju.

Dokumentiranost v slovarjih:

Murko: Mlátiti, im v. impf. dreschen $\sim$ Pleteršnik: mlátiti, -im, vb. impf. dreschen SSKJ: mlatíti in mlátiti -im nedov. 1 . s cepcem, mlatilnico spravljati zrnje iz klasja, latja $\sim$ SBG: mlátiti -in mlatiti žito PKMS: mlátiti -in mlatiti SGS: $\varnothing$

\section{(48) SLA V297 'vejati'}

T387: 'bi:ntlatị, 'vẹ:jatị; T397: 'bi:ntlati̊; T398: 'bi:ntlatị

Za pomen 'odstranjevati pleve in primesi iz žita', knj. véjati (ê), se povsod uporablja leksem bintlati, izpeljanka iz leksema bintel 'vejalnik', tvorjenega iz prevzetega leksema Wind 'veter'. Leksem bintlati ima v T387 zabeleženo dvojnico vejati, pslovan. *vě̃jati (SES: 817). Leksem vejati je za obravnavani pomen posplošen tudi v slovenskogoriškem in prleškem narečju.

Dokumentiranost v slovarjih: 
Murko: bintlati: -; Véjati, am v. impf. das ausgedroschene Getreide vermittelst der Getreidemühle oder mit der wurfschaufel von der spreu reinigen, auswinden $\sim$ Pleteršnik: bintlati: -; vẹjati, -jam, -jem, vb. impf. 1) v. žito, das Getreide worfeln, auswinden SSKJ: bintlati: -; véjati -am nedov. 1. odstranjevati pleve in primesi iz žita $\sim$ SBG: bintlati: -; véjati -an vejati, vetriti žito $\sim$ PKMS: bintlati: -, toda binklivati -an vejati; vejati: - SGS: bintlati: -, toda 'binklevvate -an nedov. vejati; vejati: ø

\section{(49) SLA V311 'klepati'}

T387: kle'påtị; T397: kle'påtị; T398: kle'påti

Za pomen 'z udarci kladiva tanjšati, ostriti rezilo', knj. klepáti (á), se uporablja leksem klepati, kar poznajo tudi v slovenskogoriškem in prleškem narečju. Pslovan. *klepäti 'tolči, biti' je domnevno iz onomatopeje *klep-, ki posnema zvoke, nastale ob trku dveh trdnih, navadno kovinskih predmetov (SES: 278; ESSJ II: 40).

Dokumentiranost v slovarjih:

Murko: klepáti, ám und pljem v. impf. dengeln Pleteršnik: klépati, klépljem, tudi: klepáti, -âm, vb. impf. 2) klopfen, hämmern, klempern SSKJ: klepáti klépljem nedov. 1. z udarci kladiva tanjšati, ostriti rezilo $\sim$ SBG: klepàti klèplen klepati $\sim$ PKMS: klèpati -an klepati SGS: $k^{\prime} l e p a t e$-an nedov. klepati

\section{(50) SLA V312 'kositi'}

T387: ko'siti; T397: ko'siti; T398: ko'siti

Za pomen 's koso, kosilnico rezati travo, žito', knj. kositi ( $(\vec{\imath})$, se uporablja enotno poimenovanje kositi, izpeljano iz leksema kosa, pslovan. *kosä 'kosa' (SES: 311); leksem kositi je za obravnavani pomen posplošen tudi v slovenskogoriškem in prleškem narečju.

Dokumentiranost v slovarjih:

Murko: Kofíti, im v. impf. mähen $\sim$ Pleteršnik: kositi, -im, vb. impf. mähen SSKJ: kosíti -ím nedov. 1. s koso, kosilnico rezati travo, žito $\sim$ SBG: kositi: $-\sim$ PKMS: kositi -in kositi SGS: ko'si:te -i:n nedov. kositi

\section{(51) SLA V313 'sušiti'}

T387: si'šitią; T397: silšitio; T398: si'šitị

Za pomen 'delati kaj suho', knj. sušiti ( $)$, se uporablja enotno poimenovanje sušiti, izpeljano iz leksema suh, pslovan. *sûxъ 'suh, ne moker' (SES: 710); leksem sušiti za obravnavani pomen poznajo tudi v slovenskogoriškem in prleškem narečju.

Dokumentiranost v slovarjih: 
Murko: Su Shiti ím v. impf. dörren, trocknen Pleteršnik: sušiti, -im, vb. impf. trocknen $\sim$ SSKJ: sušiti -ím nedov. delati kaj suho $\sim$ SBG: süšiti -in sušiti $\sim$ PKMS: süšiti -in sušiti $\sim$ SGS: $\varnothing$

\section{(52) SLA V314 'obračati seno'}

T387: ob'råčatị; T397: ob'råčatị;; T398: ob'råčatị

Za pomen 'delati, da kaj leži s spodnjo stranjo navzgor', knj. obračati (ā), se uporablja leksem obračati, pslovan. domnevno *ob(v)őrt'ati, kar je ponavljalni glagol od *ob(v)ortïti 'obrniti' (SES: 459). Leksem obračati je za obravnavani pomen posplošen tudi v slovenskogoriškem in prleškem narečju.

Dokumentiranost v slovarjih:

Murko: Obrázhati, am v. impf. wenden, oft und lange wenden Pleteršnik: obráčati, -am, vb. impf. ad obrniti: 1) umwenden, umkehren -2) wenden SSKJ: obráćati -am nedov. 3. delati, da kaj leži s spodnjo stranjo navzgor $\sim$ SBG: obràčati -áčan obračati

$\sim$ PKMS: obråčatilobráčati -an obračati SGS: $\varnothing$

\section{(53) SLA V324 'presti'}

T387: p'restì; T397: p'restį; T398: p'resti

Za pomen ' $\mathrm{z}$ orodjem ali strojem oblikovati predivo v nit', knj. prêsti in présti $(e ́$; é), se uporablja enotno poimenovanje presti, pslovan. *pręsti (SES: 569), posplošeno tudi v slovenskogoriškem in prleškem narečju.

Dokumentiranost v slovarjih:

Murko: Prè)ti, prédem v. impf. spinnen Pleteršnik: présti, prédem, vb. impf. 1) spinnen $\sim$ SSKJ: prêsti prêdem in présti prédem nedov. $1 . \mathrm{z}$ orodjem ali strojem oblikovati predivo v nit $\sim$ SBG: présti -edẹn presti $\sim$ PKMS: presti: $-\sim$ SGS: $\varnothing$

(54) SLA V326 'tkati'

T387: -; T397: -; Т398: -

Za pomen 'delati tekstilne izdelke s križanjem, prepletanjem osnovnih niti in votka', knj. tkáti (á), gradivo ne daje podatkov. Iz dodatnih pojasnil informatorjev izhaja, da tkalstvo $\mathrm{v}$ teh krajih ni bilo razvito.

\section{(55) SLA V347 'skopiti'}

T387: fko'piti; T397: fko'piti; T398: fko'piti 
Za pomen 'odstraniti spolne žleze', knj. skópiti in skopiti $(o ́$; $\bar{l})$, se uporablja leksem vkopiti, pslovan. *skopitti 'skopiti' in *kopïti 'enako' (SES: 626). Leksem vkopiti poznajo tudi v slovenskogoriškem in prleškem narečju, kjer ima dvojnico rezati, pslovan. *rě̃zati (SES: 620).

Dokumentiranost v slovarjih:

Murko: vkopiti: -, toda kopiti, ím v. impf. entmannen, kastriren $\sim$ Pleteršnik: vkopiti: -, toda skopiti, -im, vb. pf. entmannen, verschneiden, castrieren, Mur., Cig., Jan. SSKJ: vkopiti: -, toda skópiti -im, tudi skopiti in skópiti -im dov. odstraniti spolne žleze ＳBG: fkopiti -ín skopiti, rezati PKMS: vkopiti: - SGS: fko'pi:te -i:n dov. skopiti

\section{(56) SLA V385 'strojiti'}

$$
\text { T387: -; T397: -; T398: - }
$$

Za pomen 'obdelovati surovo živalsko kožo s strojili', knj. strojíti $(\bar{l})$, gradivo ne daje podatkov. Iz dodatnih pojasnil h gradivu izhaja, da strojarska obrt $\mathrm{v}$ teh krajih ni bila razvita.

\section{Zaključek}

Iz gradiva za SLA je razvidno, da se za pomene, po katerih se sprašuje in ki so predstavljeni $\mathrm{v}$ tem prispevku, $\mathrm{v}$ obravnavanih prekmurskih govorih uporablja 47 različnih leksemov, od tega so štirje večpomenski. Večinoma so enobesedni (94\%), manj je večbesednih (6\%). Z vidika izvornosti je slovanskega izvora $82 \%$ enobesednih leksemov, $18 \%$ pa jih je v različnih časovnih obdobjih prevzetih iz sosednjih jezikov, največ germanskega (75\%), ena beseda je romanskega izvora, ena pa je ali romanskega ali germanskega izvora. Med večbesednimi poimenovanji jih je največ takih, ki imajo glede na prevzetost oz. neprevzetost jedra in/ali določila domače jedro in domače določilo oz. so slovanskega izvora, ${ }^{3}$ eno pa ima prevzeto jedro in domače določilo. Sklop »kmečka opravila« izkazuje stoodstotni delež besed slovanskega izvora, medtem ko je v sklopu "gospodarska poslopja in kmečko dvorišče« $28 \%$ besed prevzetih.

$\mathrm{Na}$ osnovi opravljenih primerjav in preverb v slovarjih, s čimer osvetljujemo dokumentiranost in semantiko obravnavanih leksemov v dveh starejših slovenskih slovarjih (Murkov, Pleteršnikov), v SSKJ in treh narečnih slovarjih, ki prinašajo prekmursko besedje, je mogoče ugotoviti, da je izmed pregledanih slovarjev najbogatejši Pleteršnikov slovar, ki beleži 40 leksemov, od katerih jih je 34 pomensko prekrivnih z narečnimi, eden je pomensko prekriven, a delno

\footnotetext{
${ }^{3}$ Slovenskih tvorjenk iz prevzetih besed ali njihovih delov nimamo za prevzete (Toporišič 1992: 218). Isto velja za več kot enobesedna poimenovanja oz. besedne zveze (npr. cimermanska sekira).
} 
izrazno različen: skopiti (nar. vkopiti), dva leksema: studenec, lovič imata $\mathrm{v}$ slovarju drugačen pomen od izpričanega narečnega 'vodnjak' in 'svinjska štala', štirikrat pa v ustreznem slovarskem članku pod gesli štala, blanja in lupati dani (narečni) pomen 'hlev za krave', 'hlev za ovce', 'tanka deska' in 'ličkati' ni dokumentiran oz. nedvoumno izražen. Pleteršnikov slovar ne beleži treh večbesednih leksemov (svinjska štala, svinjske štalice, cimermanska sekira), prevzetih leksemov hajzelj, pušelj, štil, fosen ter šestih tvorjenk, od tega treh, izpeljanih iz prevzete osnove (blanjščica, bintati, štalica), in treh, izpeljanih iz domače osnove (kokošečnjek, prekal, sralnjek).

V SSKJ je zapisanih 40 leksemov, od tega jih je 33 pomensko prekrivnih z narečnimi, dva sta pomensko prekrivna, a delno izrazno različna: kokošnjak (nar. kokošečnjek), skopiti (nar. vkopiti), leksema studenec in pušelj imata $\mathrm{v}$ slovarju zabeležen drugačen pomen od narečnega 'vodnjak', 'butara', štirikrat pa v ustreznem slovarskem članku pod gesli štalica, štala in blanja dani (narečni) pomen 'hlev za svinje', 'hlev za krave' in 'hlev za ovce', 'tanka deska' ni dokumentiran oz. nedvoumno izražen. SSKJ ne beleži v gradivu izpričanih večbesednih leksemov, prevzetih leksemov hajzelj, štil, fosen ter tvorjenk blanjščica, bintati, lovič, oglenje, prekal in sralnjek.

Murkov slovar beleži 27 leksemov, ki so pomensko prekrivni z narečnimi; nadaljnji štirje leksemi so pomensko prekrivni, a delno izrazno različni:Jtudeniz (nar. studenec), drova (nar. drva), Jhelesje (nar. železo), kopiti (nar. vkopiti), leksem studenec ima v slovarju zabeležen drugačen pomen od narečnega 'studenec, manjši izvir vode', devetkrat pa v ustreznem slovarskem članku pod gesli štala, štalica, skedenj, korito, blanja, lupati, sekira dani (narečni) pomen 'hlev za krave' in 'hlev za ovce', 'hlev za svinje', 'prostor za seno', 'korito za vodo' in 'korito za svinje', 'tanka deska', 'ličkati' in 'navadna sekira' ni dokumentiran oz. nedvoumno izražen. Murkov slovar ne beleži v gradivu izpričanih večbesednih leksemov, prevzetih leksemov hajzelj, štil, fosen ter tvorjenk bintati, blanjščica, kokošečnjek, lovič, ogelje, prekal in sralnjek.

Od narečnih slovarjev je najbogatejši Novakov Slovar beltinskega prekmurskega govora, ki v enakem pomenu, kot je izpričan v gradivu, beleži 34 leksemov, od katerih so trije izrazno različni (blanjčka, mlatidev, železje), trikrat pa v ustreznem slovarskem članku (pod gesli štala in blanja) dani (narečni) pomen 'hlev za krave' in 'hlev za ovce' ter 'tanka deska' ni dokumentiran oz. nedvoumno izražen. Petnajstih, v gradivu izpričanih leksemov slovar ne beleži. Mukičev Porabsko-knjižnoslovensko-madžarski slovar beleži 32 leksemov, pomensko prekrivnih z leksemi, izpričanimi v gradivu, od katerih je en leksem izrazno različen (binklati), štirikrat v ustreznem slovarskem članku (pod gesli štala, korito in pušelj) dani (narečni) pomen 'hlev za krave' in 'hlev za ovce', 'korito za vodo' in 'butara' ni dokumentiran oz. nedvoumno izražen; leksem lupati ima v Mukičevem slovarju zabeležen drugačen pomen od v gradivu izpričanega 'ličkati'. Enaindvajsetih leksemov slovar ne beleži. Slovar Gornjega Senika Marije Bajzek Lukač beleži od 25, v gradivu izpričanih leksemov od črke A do L, dvanajst takih, ki so pomensko prekrivni z zabeleženimi leksemi, dva sta izrazno različna (binklivati, lüškiti), enkrat pa v ustreznem slovarskem 
članku pod geslom korito dani (narečni) pomen 'korito za vodo' ni dokumentiran oz. nedvoumno izražen. Desetih leksemov slovar ne beleži.

Na podlagi opravljene analize lahko sklenemo, da je besedje iz pomenskega polja "gospodarska poslopja, kmečko dvorišče in kmečka opravila« v obravnavanih prekmurskih krajevnih govorih večinoma izvorno slovansko, nekaj leksemov pa je tudi prevzetih, največkrat iz sosednjega stičnega nemškega jezika. Preverba njihovega obstoja v knjižnih in narečnih slovarjih kaže, da je sodobna izrazna pestrost prekmurskega narečja v največji meri dokumentirana v Pleteršnikovem slovarju, ki mu sledi SSKJ. Med pregledanimi narečnimi slovarji največ v gradivu dokumentiranega narečnega besedja prinaša Novakov Slovar beltinskega prekmurskega govora.

Narečno prekmursko besedje, predstavljeno $\mathrm{v}$ tem prispevku, pri srednji in mlajši generaciji govorcev hitro tone $\mathrm{v}$ pozabo, zato njegova predstavitev predstavlja droben, a pomemben prispevek $\mathrm{k}$ ohranjanju slovenske jezikovne kulturne dediščine.

\section{KRAJŠAVE IN KRATICE VIROV}

avstr. - avstrijsko; bav. - bavarsko; češ. - češko; dalm. - dalmatinsko; furl. - furlansko; gl. - glej; hrv. - hrvaško; istr. - istrsko; it. - italijansko; knj. - knjižno; nar. - narečno; nem. - nemško; pslovan. - praslovansko; rom. - romansko; rus. - rusko; sed. - sedanjik; sloven. - slovensko; srb. - srbsko; srvnem. - srednjevisokonemško; stvnem. - starovisokonemško; drugo: DLS - Deutsche Lehnwörter im Slovenischen Striedter-Tempsove, ESSJ I-IV - Bezlajev Etimološki slovar slovenskega jezika, PKMS - Mukičev Porabsko-knjižnoslovensko-madžarski slovar, SBG - Novakov Slovar beltinskega prekmurskega govora, SGS - Slovar Gornjega Senika A-L Bajzek Lukačeve, SES - Snojev Slovenski etimološki slovar, SSKJ - Slovar slovenskega knjižnega jezika

\section{VIRI IN LITERATURA}

Anton BAJEC idr. (ur.), 1995: Slovar slovenskega knjižnega jezika. Ljubljana: SAZU.

Marija BAJZEK LUKAČ, 2009: Slovar Gornjega Senika A-L. Maribor: Mednarodna založba Oddelka za slovanske jezike in književnosti, Filozofska fakulteta. (Mednarodna knjižna zbirka Zora, 66).

France BEZLAJ, 1976-2007: Etimološki slovar slovenskega jezika I-V. Ljubljana: SAZU.

Mihaela KOLETNIK, 2008: Panonsko lončarsko in kmetijsko izrazje ter druge dialektološke razprave. Maribor: Mednarodna založba Oddelka za slovanske jezike in književnosti, Filozofska fakulteta. (Mednarodna knjižna zbirka Zora, 60).

Mihaela KOLETNIK, Zdenka HOLSEDL, 2009: Zemljepisna lastna imena v Večeslavcih. Jezikoslovni zapiski 15/1-2, 173-187. 
Francek MUKIČ, 2005: Porabsko-knjižnoslovensko-madžarski slovar. Szombathely: Zveza Slovencev na Madžarskem.

Anton J. MURKO, 1833: Deutsch-Slowenisches und Slowenisch-Deutsches Handtwörterbuch. /.../ Slovensko-Nemshki in Nemshko-slovenski rozhni besednik. /.../. V Gradzi.

Franc, Vilko NOVAK, 1996: Slovar beltinskega prekmurskega govora. Murska Sobota: Pomurska založba.

Maks PLETERŠNIK, 2006: Slovensko-nemški slovar (1894-1895): transliterirana izdaja. Ur. M. Furlan. Ljubljana: ZRC SAZU.

Vera SMOLE, Urška PETEK, 2007: Komentiranje leksično-besedotvornih kart v 1. zvezku Slovenskega lingvističnega atlasa »Človek« (na primeru V617 teta in V 618 ujna). Jezikoslovni zapiski 13/1-2, 351-359.

Marko SNOJ, 2003: Slovenski etimološki slovar. Ljubljana: Modrijan.

Hildegard STRIEDTER TEMPS, 1963: Deutsche Lehnwörter im Slovenischen. Berlin: Osteuropa-Institut Berlin.

Mateja SEVER, 2014: Besedje po vprašalnici za slovenski lingvistični atlas v izbranih prekmurskih govorih. Diplomsko delo. Maribor. Filozofska fakulteta.

Jožica ŠKOFIC (ur.), 2011a: Slovenski lingvistični atlas 1.1, Človek (telo, bolezni, družina), Atlas. Ljubljana: ZRC SAZU.

Jožica ŠKOFIC (ur.), 2001b: Slovenski lingvistični atlas 1.2, Človek (telo, bolezni, družina), Komentarji. Ljubljana: ZRC SAZU.

Jože TOPORIŠIČ, 1992: Enciklopedija slovenskega jezika. Ljubljana: Cankarjeva založba.

Zinka ZORKO, 2009: Narečjeslovne razprave o koroških, štajerskih in panonskih govorih. Maribor: Mednarodna založba Oddelka za slovanske jezike in književnosti, Filozofska fakulteta. (Mednarodna knjižna zbirka Zora, 64).

DIALECTAL PREKMURJE LEXEMES FOR FARM BUILDINGS, FARMYARDS, AND FARM CHORES IN PLETERŠNIK'S DICTIONARY

This article presents lexemes denoting farm buildings, farmyards, and farm chores in the Prekmurje dialect to the extent specified in the questionnaire used for the Slovenian Linguistic Atlas (SLA). In the SLA's questionnaire, the above-mentioned lexemes are found in six different sections, including the one dealing with grammar. Based on semantic criteria, the Dialectological Section of the Fran Ramovš Institute of the Slovenian Language ZRC SAZU has classified these lexemes into farm buildings and farmyards (38 questions). To this, we added farm chores (18 questions). Observations based on the data gathered from three local dialects in the period between 2013-2014 show that the Prekmurje dialect uses forty-seven different lexemes, forty-four single-words, and three multi-words for the items under investigation. The lexemes are heterogeneous in terms of their origin. About $82 \%$ single-word lexemes are of Slavic origin, $18 \%$ were adapted from the neighboring languages, most of them from German (75\%). Multi-word 
lexemes are primarily of Slavic origin. A comparative analysis of the lexemes' inclusion into dictionaries reveals that most of them are found in Pleteršnik's dictionary and in SSKJ. The greatest number of those that semantically overlap with dialectal lexemes are included in Pleteršnik's dictionary. In the dictionaries that include the Prekmurje dialect vocabulary, the most lexemes are found in Novak's dictionary. The dialectal vocabulary of the Prekmurje dialect analyzed in this article is now almost forgotten by middle-aged and younger generations, which is why this study represents a small, but nevertheless important contribution to the preservation of the Slovene linguistic cultural heritage. 